\title{
Photovoltaic solar energy, spearheading Germany's renewable energy policy: an example to others
}

\author{
W. Palz ${ }^{\mathrm{a}}$ \\ University of Karlsruhe, CNES Programmes Division University of Karlsruhe, Belgium
}

Received: 4 March 2012

Published online: 26 June 2012

\section{Photovoltaic (PV) energy in Germany today, in January 2012}

Since the end of 2011, the PV installations in Germany have reached a capacity of $25 \mathrm{GW}$ or $25000 \mathrm{MW}$. For comparison: Italy now has $12 \mathrm{GW}$ and France has $2.5 \mathrm{GW}$. Thus, despite the modest amount of sunshine it receives, Germany is bolstering its world record in this new industrial sector.

German individuals and communities (rather than conventional electric companies) have been swept up in a major trend and have massively invested in more than one million individual PV systems. Despite the non-negligible importing of PV modules from China, 120000 jobs were created in Germany in PV-related industrial production, small industry, and services.

With its 25 GW, PV already accounts for a significant proportion of the total equipment required to supply electricity to the whole of Germany, whose requirements at peak hours are $80 \mathrm{GW}$. Because the availability of solar power generation is more limited than conventional sources of electricity, the energy contribution of $\mathrm{PV}$ did not exceed 20 TW h over the entire year 2011. Compare this to the total net electricity consumption for the whole of Germany, which was $500 \mathrm{TWh}$ in 2011. The average contribution of $\mathrm{PV}$ to electrical consumption is therefore close to $5 \%$. In certain regions, such as Bavaria, with its more abundant solar resources, the contribution already exceeds $10 \%$.

Now, in January 2012, the cost of PV in Germany has reached 'grid parity' for the first time. At 25 cents per $\mathrm{kWh}$, the latest PV price drop, which has just come into force, brings PV down to the cost price of electricity for private individuals who are network subscribers. This is also true in Italy, but not in France, where the price for EdF subscribers is much lower.

\footnotetext{
a e-mail: w@palz.be
}

\section{German PV projection for 2020}

Within the framework of the EU Energy and Climate Directive of 2010, Germany is committed to deploying PV equipment with total capacity of $51 \mathrm{GW}$ by 2020. In view of the momentum PV is now enjoying in Germany, some experts even predict that a capacity of around $60 \mathrm{GW}$ will be reached.

By way of comparison: France's commitment with regard to this Directive is $5.4 \mathrm{GW}$ by then - only a tenth of what its German cousins plan to achieve. This would amount to producing 1 or $2 \%$ of the nation's energy consumption. This is little more than background noise. More recently, the authorities in Paris have started talking about figures of 7 or $8 \mathrm{GW}$, and professional association SER in France has suggested $20 \mathrm{GW}$ in its recent Whitebook on the RE...

But an outside observer would probably find it strange that France, with its famously sunny Côte d'Azur, amongst other areas, seems to take such a hesitant approach compared to its German neighbour which, as the Americans point out, receives the same amount of sunshine as Alaska.

\section{Photovoltaic energy worldwide since 2011}

According to preliminary figures, in 2011 the world installed $28 \mathrm{GW}$ of additional PV; a $50 \%$ increase compared to 2010 .

There has been consistent worldwide growth of PV installations year on year since 1980: in 1980 the very modest figure of $1 \mathrm{MW}$ was exceeded for the first time, and in 2008 the $10 \mathrm{GW}$ barrier was broken.

Currently, the global installed PV capacity is $71 \mathrm{GW}$, of which $66 \mathrm{GW}$ is connected to networks, and approximately $5 \mathrm{GW}$ supplies stand-alone electrical power. The growth rates are impressive. At the end of 2010, there was only $38 \mathrm{GW}$ of PV supplying the world's electrical networks. 
Solar cells have respectable efficiency levels: $37 \%$ has been reached under laboratory conditions, and with light concentration, even $43 \%$ has been achieved. The PV markets, which are clearly global in nature, are always dominated by silicon modules with approximately $20 \%$ efficiency. Thin film modules (CdTe, CIGS, etc.) are becoming increasingly important. Their efficiency is limited to around 10 to $15 \%$, but they are cheaper to manufacture than silicon modules.

Module prices have fallen considerably. A drop of about one third occurred in 2011 alone. In Europe, where the bulk of world market activity takes place, prices of $€ 800$ per $\mathrm{kW}$ were achieved on the spot market in late 2011. For complete systems, without storage, prices went down to about $€ 2000$ per $\mathrm{kW}$. Also note that, in the USA, the prices of small systems can be $60 \%$ higher than the prices seen in Europe. The spectacular drop in prices is not only due to larger-scale production chains, but also because manufacturers worthy of the name invested in production chains of one GW per year or more.

In fact, a PV bubble has burst.

This good news for investors has become a nightmare for the module manufacturers. Almost all, including Chinese manufacturers, are compelled to sell at a loss because market prices are well below production costs. They need to liquidate the stock they built up following the euphoria of recent years. The current worldwide production capacity of solar modules is double the market requirement, reaching $50 \mathrm{GW}$ per year. Many of the production chains have obviously been shut down. Almost all of the manufacturers finally experienced a drop in their share values, by an average of $70 \%$ in a year, and quite a few went bankrupt. Suntech, the world leader, located in Wuxi/Shanghai, hopes to return to making a profit sometime around mid-2012 at the earliest.

In conclusion: the current prices of modules do not reflect industrial maturity. They should not fall any more until the improvements made to the current production tools have had their effect. Ultimately, module production costs, whatever the technological process used, will hit a hard limit of $€ 500$ per $\mathrm{kW}$...

\section{The environment in the energy world of 2011}

Over these last 20 years, the world gained an extra $1 / 4$ of electricity production capacity in the form of renewable energy, and only 2\% in nuclear capacity. In 2011 alone, 11.5 GW of nuclear capacity was permanently shut down, and only $1.5 \mathrm{GW}$ was put in service. Without China's major investments in coal, renewable energy sources would have exceeded world investment in coal-fired power plants.

In 2011, global investment in renewable energies was $\$ 260$ billion or $€ 200$ billion, half of it for PV. Germany took second place, behind China.

For the time being, wind power is maintaining the top spot amongst renewable energy sources. At the end of 2011, a total of 240 GW are globally connected to the networks, including almost 40 GW added in 2011 alone. With a total installed capacity of 29 GW, Germany is still holding third place in the world, behind China and the USA, but in front of Spain and India.

Finally, last year was marked by the decline of concentrating solar power (CSP). For decades, this technology was promoted by the Germans, led by DLR and Solar Millennium AG. That was also the reason behind their inventing the 'Desertec' programme, given that CSP installations work better in the desert than they do in Germany. Those who were slow to understand this fact discovered it at their own expense: PV is quite simply cheaper than CSP. Eventually, in 2011, the champion of the sector, Solar Millennium, declared bankruptcy and, despite a loan guarantee from the American Government, the 7 GW produced by CSP solar power plants in California and elsewhere in the USA were gradually replaced by PV. The waste was halted just in time.

Finally, a word about subsidies. Certain people criticise renewable energy because it requires political and budgetary promotion. Experts in the field point out, however, that their lack of indirect cost can validly be compensated for by support for the State or public funds in general. And, to view the energy situation as a whole, it should be pointed out that, according to the OECD and the IEA, and despite the fine declarations of the G20, the world is currently devoting 500 billion dollars to subsidising fossil and atomic energy sources, which the authors claim is to the detriment of the development of renewable energy sources and energy efficiency.

\section{Germany's radical conversion to renewable energy sources}

In $2011,20 \%$ of the net electricity consumption in the Federal Republic was supplied by renewable sources. This represents a doubling of the percentage in just seven years.

Renewable electricity exceeded nuclear energy consumption for the first time. More than half the renewable electricity consumed came from the sun and the wind. PV came in third place, after wind power and bioelectricity, and overtook hydroelectric power consumption for the first time.

This is not just a result of the 'Fukushima Effect'. Well before the Japanese disaster, Germany had decided to change tack in terms of energy policy. In 2020, the $20 \%$ of renewable electricity we have today will rise to more than $35 \%$ of net total consumption in accordance with the official policy.

In Germany, there is already a very high power capacity of $54 \mathrm{GW}$ of intermittent electricity, which is therefore random and difficult to program. This includes $29 \mathrm{GW}$ of wind power and $25 \mathrm{GW}$ of $\mathrm{PV}$. This is huge, given the maximum annual capacity demand, which is only $80 \mathrm{GW}$. By 2020, the intermittent electricity capacity could easily exceed $100 \mathrm{GW}$, including $60 \mathrm{GW}$ for PV and more than $40 \mathrm{GW}$ for wind power. But we should note that the Germans have already succeeded in controlling these 
W. Palz: Photovoltaic solar energy, spearheading Germany's renewable energy policy: an example to others

intermittent energy sources. The proof: in four Länder in northern Germany, wind power is abundant, and in 2011 it already contributed $45 \%$ of all electricity consumption.

\section{Solar and anti-nuclear Germany: the other side of the coin}

Most Germans are very much in favour of developing solar power. But that view is not necessarily shared by the 'elite' and the politicians. A political leader was therefore needed to lead the battle in favour of renewable energy sources. This person was my friend Hermann Scheer. Before he died in late 2010, he was for 30 years an SPD member of the Bundestag. He was a great strategist and a political unifier who could rally opinion well beyond his own party.

H. Scheer discovered renewable energies in the 1980s, during his time as his party's disarmament correspondent. That was the era of the arms build-up decided on by NATO, in which Chancellor Helmut Schmidt (SPD) played a part. The western powers thereby achieved the break-up of the USSR, but they were playing with fire, because both Germanies were loaded up to the hilt by the Americans and Russians with an atomic arsenal that could have blown up the whole planet. H. Scheer concluded that we needed to change our society in a fundamental way and increase individual responsibility, starting with a decentralized energy system, which should therefore be solar.

H. Scheer succeeded in persuading his colleagues in the Bundestag to vote for a law favouring the deployment of renewable energy, starting in 1990 for wind power, and the early 2000s for PV and bioenergies. With the arrival of Angela Merkel (CDU), he found a Chancellor who was personally committed to taking the IRENA project forward; this was the International Renewable Energy Agency, which has since become established, with more than 150 member countries all over the world.

Note that, overall, renewable energies have received the same favourable treatment under a Conservative-led government as they did previously under the 'Left'. The EU Energy and Climate Directive was initiated under the German presidency of the Council, and with the personal commitment of Chancellor Merkel. The Minister N. Röttgen, currently in charge of renewable energy in Berlin, oversees their development.

Wolfgang Palz

Ph.D. in Science, University of Karlsruhe Former Engineer in the CNES Programmes Division,

Paris

Former Official the EU Commission, Brussels World Council for Renewable Energy, Bonn 